\title{
Freedmen in Context: \\ Reconsidering the Role of the Freedmen's Bureau in Reconstruction Histories
}

\author{
Courtney Walcott
}

The U.S. Bureau of Refugees, Freedmen and Abandoned Lands, popularly known as the Freedmen's Bureau, was integral in the establishment of Reconstruction policies toward both freed slaves and white refugees in the fallout of the American Civil War. Scholarly work, however, regarding the Freedmen's Bureau's efficacy and allegiances has proven to be contradictory. Historians have either held the Freedmen's Bureau responsible for helping Freedmen adjust to post-emancipation life or they suggest that the Freedmen's Bureau actually helped usher in and re-establish a plantation economy in the South similar to that of slavery. There is a conflict within the nature of history. Historians try to interpret facts and create historical narratives, however, these narratives are impossible to separate from the context of the historian. Someone who lived through the heights of Jim Crow will always craft a narrative that is contextually unique from the historian dealing with post-Civil Rights Reaganomics. Context is everything.

Early scholarship regarding the Freedmen's Bureau was influenced by the racial realities of post-emancipation and post-Reconstruction. These discourses, emerging in the first few decades of the twentieth century, regarding the Freedmen's Bureau suggested that it failed due to Republican political interference and the enforcement of privileged Reconstruction policy over the aims of the Freedman's Bureau. This gave way to revisionist historians who, from the 1950's through the 1980's, would argue whether the Freedmen's Bureau was a perpetrator of oppressive policies toward Freedmen or if it simply was a powerless governing body impressed upon by larger political forces. In reading these histories, students would be directed toward understanding the Freedmen's Bureau through specific historical viewpoints that shaped its reputation without a full consideration of the context within which these histories were developed. Eventually, in the early 2000's, the emerging trends of Freedmen's Bureau histories adjusted toward a hybrid understanding of the Bureau. The growing focus around the turn of the century found scholars writing about the Freedmen's Bureau from the point of view of the Bureau itself, which contributed to an overall image of the Bureau that did not align with historian's previous characterizations, choosing rather to focus on the difficulties of navigating race relations and a free economy during Reconstruction. This new generation of writing on the Freedmen's Bureau attempted to navigate between the two opposing identities of the Bureau by focusing on the deep dichotomy between political directives, economic opportunities, prejudice and the actual expectations and desires of the newly emancipated populations. In examining the historical trends of Freedmen's Bureau discourses, this essay will showcase the problematic identity that has characterized the Bureau from its earliest inception as it grew into the more complex and textured identity that was the result of these complex discourses. 
As an "instrument of Reconstruction," the Freedmen's Bureau found itself responsible for ensuring the rights and freedoms of ex-slaves were not infringed upon by any lingering pro-slavery sentiments. ${ }^{i}$ The early twentieth century saw histories of the Freedmen's Bureau focus primarily on the idea that the Bureau was now responsible for the Freedman problem, which constituted of a large group of laborers who found themselves without any responsible recourse. C. Mildred Thompson wrote, in her essay on the Freedmen's Bureau for the Georgia Historical Quarterly, "To the Southerner of the late sixties and the seventies, the Freedmen's Bureau constituted undoubtedly one of the chief elements in the barbarism of reconstruction. ${ }^{\prime i i}$ The focus of her essay constructed the idea that the Freedmen's Bureau encouraged the economic dismantling of southern society. Thompson argues that "The Southerner" in this time fell victim to destitution due to a lack of a labor force that provided the means for both the owner and the workers to survive. The economic failure of the southern states was in part due to the monetary support the Bureau supplied to freedmen that allowed them to desert the plantation lifestyle for the "charms of city life."iii Thompson suggested that the Bureau facilitated the dependency of freedmen on government money. This dependency allegedly led to an influx of ex-slaves leaving their old plantations and entering into city life, further condemning southern landowners by supporting, if not encouraging, the slaves abandonment of the labor lifestyle that once kept them both fed. Thompson acknowledges, however, that the Freedmen's Bureau was complicated in the sense that it did not want to encourage such vagrancy but nonetheless facilitated it. She points out that Freedman Bureau Agent General Davis Tillson issued orders that would limit or outright deny any form of rations to an "able-bodied negro for whom work could be found."iv Thompson fostered an image of internal conflict within the Freedmen's Bureau and its policies regarding how to solve the problem of the freed slaves population and refugees, having to balance the interests of both the southern white economy and the Freedmen's interests.

The Freedmen's Bureau dealt with criticisms that its policy supported the ideas of dependency. Before the Bureau was even created, Congress went back and forth regarding how to effectively integrate ex-slaves into the nation's workforce. Thompson's argument reaffirms some of the initial fears that the Bureau, in its monetary support of ex-slaves, created a dependency that was counter-productive to the aims of solving the Freedmen problem.

This negative view of the Bureau, as an agency that created policies that essentially crippled the southern economy, continued on for decades within historical discourse. The racial undertones of this argument act as a launching pad for many revisionist historians who saw that the failure of the black community to succeed and excel alongside whites was due to the failures of policy in the Freedmen's Bureau and not due to outside forces. An important distinction that Thompson makes, that recurred in future histories of the Freedmen's Bureau, is that the Bureau struggled to mitigate the contract work of slaves, while decreasing dependency and helping to reestablish an economic system that once relied on slavery. Thompson argues that General Tillson went to great lengths to ensure freed blacks were entering into work contracts, being careful to not only protect the interests of freedmen, but also of the white land owners. ${ }^{v}$ Therefore, according to Thompson, the Bureau acted as a paternal organization, attempting to usher in an age of cooperation between the opposing forces of blacks and whites. 
Thompson's essay sets the stage for years of discourse regarding the Freedmen's Bureau. She took no specific stance on whether or not the Freedmen's Bureau supported exslaves or ex-slave owners and chose to remain ambiguous by giving examples of the Bureau supporting both. The point of her essay was to take an overall look at the efficacy of the Bureau in mitigating the emerging problems of Blacks in the Reconstruction. In doing so, she established the undertones that would create a divide between historians in the ensuing decades. She provides the base for the arguments that arise in the 50's and carried through to the early 80 's that point to the Bureau being ineffective in its aims because of external interference from the government as well as the non-compliance of local racist civilians in the South. The other side of the argument that existed in this time noted the complacency of the Bureau when dealing with the capitalist interest of white Americans. The 70's was a decade of criticism for the Freedman's Bureau as several historians condemned it as a government entity that essentially worked more for the re-establishment of the plantation system than for the realization of African-American ambitions. The two sides of this debate formed two distinct historical representations of the Freedmen's Bureau, which resulted in the creation of opposing factions of Freedmen's Bureau histories, one that represents the Bureau as the victim and the other, which represents the Bureau as the perpetrator.

Martin Abbott, a notable Bureau-as-victim historian, wrote an essay in 1956 titled "Free Land, Free Labor, and the Freedmen's Bureau" that went into great detail to show that the Bureau was crippled in its earliest stages by a government which did not provide sufficient funding, and by President Johnson, who undercut the program with various forms of legislation and executive decisions at several critical stages of Reconstruction. Abbott first worked to establish the idea that the Freedmen's Bureau worked solely to satisfy and expand the ideals of " 40 Acres and a Mule" by examining the efforts that General 0. 0 . Howard went too in his determination to establish freedmen colonies and a self-sufficient freedmen population. He then argues simply that the lack of and subsequent diminishing of funding for the department created obstacles that made it impossible for ex-slaves to succeed in the Reconstruction economy. ${ }^{\text {vi }}$ One of the most important aspects of the Bureau was the maintenance of the Sea Islands and any other confiscated land that was originally specifically legislated to wards of the Freedmen's Bureau. However, even this aspect of the Bureau was stripped away by President Johnson's Amnesty Proclamation that allowed for ex-confederate landowners to reclaim confiscated property. This change in policy was seen as "financially crippling to the Bureau and severely unjust to the freedmen."vii Abbott, as a Bureau sympathizer, points to these events as the main reasons for the Bureau's failures, thereby establishing the case that the Bureau was a victim of external forces that impeded any opportunities for success in its aims.

Claude Oubre, a Bureau sympathizer, wrote his essay "Forty Acres and a Mule': Louisiana and the Southern Homestead Act" where he corroborates much of Abbott's beliefs regarding the doomed nature of the Freedmen's Bureau's policies. His main point, the failure of the Southern Homestead Act of 1866, was the examination of the confiscation of land in certain southern states for the specific purpose of allowing freedmen to establish themselves on the land. Allowing for leasing, preemption, and other methods of purchasing the land, The Southern Homestead Act offered an opportunity for ex-slaves to establish themselves in a way similar to that of the Sea Islands. Oubre uses the specific example of the Freedmen's Bureau office closures and the inhabitable land made available to homestead in Louisiana to support his claims that political interference made it impossible for the 
Freedmen's Bureau to accomplish its aims in the state. Oubre first points out that the racial climate in the south was still very negative, and that "any provisions intended for the exclusive benefit of blacks and loyal whites aggravated the existing racial and political tensions." "viii Oubre argued that racial tensions dominated the political landscape of the Reconstruction era, in particular when sweeping freedmen programs resulted in the preferential treatment of ex-slaves and loyal white over the traditional upper class of the pre-Civil War era. To further exemplify the fact that the failures of the Freedmen's Bureau were contingent on government interference, he makes a strong point to note that President Johnson decided to "close the offices at Opelousas and Greensburg [making] it impossible for homesteaders to file entry before January $1^{\text {st }}, 1867$, the deadline for exclusive entry for blacks and loyal whites."ix This closing of the offices prevented anyone from taking advantage of the land prior to it being open to purchase from people of any background, thereby undermining any opportunity the Southern Homestead Act had of success in Louisiana. Oubre would go on to further explain the lengths to which he saw government interference:

Since appointments of registers and receivers were made by the president, he could subvert the intention of the Southern Homestead Act by simply refusing to appoint either one of these officers in a state, and, indeed homesteading actually was delayed in most Southern states because of the absence of the register or receiver. Therefore, one can only question the president's intention. ${ }^{\mathrm{x}}$

Oubre's point affirms his stance regarding the Bureau and government interference. He argues that the Freedman's Bureau attempted to garner freed slaves some political and civil rights by way of land ownership, however, the lack of economic security achieved any gains made for this population momentary. ${ }^{\mathrm{x}}$

Corroborating Oubre's arguments, James Oakes, in his 1979 essay "A Failure of Vision: The collapse of the Freedmen's Bureau Courts" makes similar claims that President Johnson directly interfered with Freedmen's jurisdiction and limited the Bureau's reach in resolving local racially charged issues. The Freedmen's Bureau built itself on the premise that the "elimination of discriminatory legislation" would inevitably lead to justice for freed slaves. ${ }^{\text {xii }}$ This proved incorrect as Oakes clarifies that the court systems in the south still had a predominately racist mindset. Oakes would state, "Freedmen were often jailed without bail or were victimized by the capricious acts of local police beyond the control of the Bureau," thus affirming the limitations of the Bureau's reach in local affairs. xiii The court systems could not afford to lose their power to the Bureau, so they complied with all of General 0. 0. Howard's stipulations. However, these stipulations that on paper guaranteed Freedmen some semblance of justice and the guarantee of a fair trial were often undermined. Oakes noted, "Many agents came to realize that harshly unjust practices could go on even if state laws made no distinctions of race and colour."xiv He points out the limited reach of the Bureau, only able to amend laws and unable to guarantee their enforcement. This is where blame is placed again on President Johnson: "Not only did he fail to involve the justice department in the legal protection of the blacks, but as Howard later wrote, the President's opposition to the Bureau had caused the law "to be violated in the spirit, if not in the letter, so as to render it nugatory."xv 
The Bureau-as-victim historians all point toward the same thing; there were insurmountable obstacles that prevented Bureau policy from creating an effective system to deal with the Freedman and refugee problem. The assertions that President Johnson continually made decisions that worked against the Bureau policy, from the Amnesty Proclamation to his unwillingness to act in favour of Blacks being discriminated against in the judicial system. The Bureau-as-victim argument is based on the idea that very few options were available to the Bureau when trying to enact its aim of successfully integrating Freedmen into society. The historians of this argument use all of the evidence that demonstrate how U.S. government restricted the Freedmen's Bureau and actively stood in the way of its success.

The other side to this argument, the Bureau-as-oppressor set of historians, crafted their arguments around the ideologies of capitalism found within the Freedmen's Bureau's actions and how they conflicted with the alleged ideologies that the Bureau was established on. From its inception, the Bureau was torn between two ideologies, the Laissez-Faire ideology, most famously summed up by Frederick Douglass when answering the question of what to do with the slaves now that the war is over: "Do nothing with them, your doing with them is their greatest misfortune."xvi This mentality of a hands-off approach to the assimilation and establishment of freedmen in Reconstruction society affected many revisionist historians views of the Freedmen's Bureau's actions. Often associating decisions made by the Bureau as a way of re-establishing the economy as it had been prior to the war, which was a free, hands-off, market. In an 1984 essay titled "Black Immobility and Free Labour: The Freedmen's Bureau and the Relocation of Black Labor, 1865-1868," William Cohen points out the people in this time "believed that the way and emancipation had destroyed the equilibrium that previously existed between labor supply and labor demand."xvii This assertion is the backbone of the "Bureau as oppressor" argument because it established a need for the balance to be restored, which this particular sect of historians argued was the job of the Freedmen's Bureau.

Following the Amnesty Proclamation, it fell to the Freedmen's Bureau to remove the ex-slaves from previously confiscated lands. Leon F. Litwack, in his book Been in the Storm So Long: The Aftermath of Slavery, contends that the Freedmen's Bureau, in fear of vagrancy and dependency, "made every effort to rid urban centers of black refugees and to force them back onto the plantations." xviii He argued that the Freedmen's Bureau believed that it was in the slave's best interest to return to work on the plantations and to join sign contracts that would give them a living wage that they themselves could not gather on their own. ${ }^{\text {xix }}$ Litwack vilified the Freedmen's Bureau in his book by asserting that they were pressuring ex-slaves to return to plantations to gain the favour of the Republicans, while telling themselves that contracts on plantations were in the freedmen's best interests.

Litwack argues that the Freedman's Bureau "ultimately facilitated the restoration of black labor to the control of those who had previously owned them." xx This assertion is supported by other historians who examined the activities of the Bureau in its complacency with President Johnson's aims to restore land to previous owners and to allow for blacks to become wage-earner employees on these plantations.

Herman Belz, in his 1975 essay “The Freedmen's Bureau Act of 1865 and the Principle of No Discrimination According to Color," examines the earliest controversy of the Freedmen's policies: 
On the one hand it seemed necessary to provide temporary support for the freed slaves and protect them against injury and hostile treatment, especially in the form of apprenticeship arrangements that might be merely de facto serfdom. On the other hand almost all republicans desired to recognize the emancipated people as freemen with the same rights, responsibilities, and personal freedom as ordinary citizens, understanding of course, that this did not entail political or social equality. ${ }^{\mathrm{xxi}}$

Belz elaborates on the Laissez-Faire argument for post-emancipation politics by suggesting that there was an understanding of the immediate need for post-war support for Freedmen, but that that was carefully weighed with the Frederick Douglass approach of leaving the Freedmen to their own devices. The Bureau chose a middle ground according to Litwack. The Bureau did not outwardly support untouched freedom, it felt it needed to protect the liberties of ex-slaves, however, it became the primary enforcer of contracts that returned freedmen to the plantations they had just run away from, under newer, and more emancipation-friendly terms. These new contracts were put into place to reestablish the economy after the fallout of the Civil War. Litwack notes that the removal of blacks from plantations was devastating to the economy as well as to the white southerners, prompting an immediate urgency to restore to their labour force. ${ }^{x x i i}$ Belz would corroborate this idea when he mentioned that the Freedmen's Bureau created policies that Republicans intended to use to "uphold the interests of loyal white refugees in the South."xxiii

Historians have picked apart the policies of the Freedmen's Bureau, often finding policies that in retrospect were counterproductive to the public aims of the Bureau. One historian who analyzed the policies of the Freedmen's Bureau was William Cohen. Despite being a more moderate Bureau-as-oppressor historian, William Cohen argued that the reestablishment of the slave system via wage labor was one of the goals of the Freedmen's Bureau. He pointed to the establishment of mobility agreements that removed Freedmen from areas where there were no employment opportunities to area that were in desperate need of laborers, effectively redistributing Freedmen across southern plantations under the premise of contract labor. ${ }^{\text {xxiv }}$ Believing that dependency and vagrancy were problems that faced the freedmen population, ex-slaves were redistributed across the South to meet employment demands. Cohen explained that in recent histories of the Freedmen's Bureau, "its leaders have been the focus of much criticism from scholars who have depicted [the mobility systems] as working almost in alliance with the planters to create a labor system that was only nominally free."xxv Cohen cements his argument that the mobility agreements that saw Blacks shipped across the south essentially fostered a similar system to that of slavery, all with the purpose of rebalancing the economic picture of the South.

Eventually, from the late 1980's through the first decade of the twenty first century, historians began to contextualize the complexities of the Freedmen's Bureau. Essentially blending the two conflicting identities established by Abbott, Belz, Cohen, Litwack, Oakes and Thompson and others, new histories emerged that created a new identity for the Freedmen's Bureau, one that is characterized by several unique policy successes and failures following the Civil War. An early example of this new image of the Freedmen's Bureau is Paul A. Cimbala's essay “The Freedmen's Bureau, the Freedmen, and Sherman's Grant in Reconstruction Georgia, 1865-1867." Cimbala examined the presence of both aspects of the Victim/Oppressor binary among the confiscated lands that came out of Sherman's Special Field Orders No. 15. Cimbala noted that it was the Bureau's responsibility 
to establish legitimate claims to the land as well as remove illegitimate claimants from properties that were to be restored to their previous owners. ${ }^{\text {xvi }}$ He characterizes the conflicting identities of the Freedmen's Bureau as separate reactions to the different responsibilities the Bureau was tasked with. In many scenarios, they were deemed oppressive because they were required by policy and legislation to remove illegitimate claimants from the land, which was then contrasted in other scenarios with the long-term efforts of the Bureau to protect freedmen and their proper land claims. Cimbala argues that the actions, comments, and motivations of the Bureau agents in the area reaffirmed the belief that the government would support the Freedmen's cause. ${ }^{x v i i}$ It seemed that Bureau Agents in this Ogeechee district of Chatham county in Georgia were reluctant to forcefully remove people from the land. ${ }^{x x v i i i}$ Cimbala chooses to focus on both the contract workers and the non-contract workers and how they subsisted along this region. He points out that, much like many legislators whom support the wage system insisted, contract workers who were able to use plantation facilities of the white landowners were more likely to turn a profit. ${ }^{\text {xix }}$ Cimbala suggests that part of the reason the Bureau insisted on contract work was to allow Freedmen quicker access to the economic freedom that they sought on their own. This assertion had a double effect, it seemed to many that this was a method to bring the coloured workforce back into the hands of plantations owners, whereas Cimbala suggests this was merely a logical action because of the mutual benefits offered to both parties involved. The distrust between Freedmen and white plantation owners was justified, noting that the decisions made by some not to sign contracts for wage labor was in fear of the ways this system could exploit their labor. To contextualize the complicated nature of Freedmen's decision to ignore wage labor, Cimbala references a Bureau agent's observations that Freedmen "not being driven by master or overseer, go to their work early and gladly, and the body shares the healthfulness of the mind." $x x x$ Cimbala uses these conflicting examples to demonstrate the complicated nature of the Freedmen's Bureau's responsibility to their wards, often supporting their outright freedom, whilst also attempting to effectively engage them in an economic system that could potentially expedite their path to economic freedom and sustainability through short term wage labor rather than subsistence.

Willie Lee Rose characterized the Bureau similar to Cimbala, but about twenty-five years prior. Rose describes the efforts of the Bureau as obstructive to the aims of the Johnson Administration. Rose found numerous examples of General 0. 0. Howard and other members of the Freedmen's Bureau working within their rights to delay, obstruct, or prevent any measures that were unfavorable toward freedmen. Rose points to an example where a White plantation owner "complained that Captain Ketchum would not compel contracts... unless the owners are willing to lease or sell to the freedmen."xxxi This particular example concurs with Cimbala's assertion that Bureau agents were actively seeking a solution that worked within their legislative rights whilst ensuring the most beneficial outcome for freedmen in this post-Civil War economy. Willie Lee Rose describes the Bureau as an agency on a time restraint. According to Rose, the Bureau had a short amount of time to achieve its aims, which often were in direct opposition to the Johnson Administration, which resulted in actions taken by the Bureau to prolong its own existence. ${ }^{\text {xxii }}$ Rose's characterization of the Bureau is unique in the sense that he describes the Bureau as being active in the protection of freedmen's rights while attempting to attain a reasonable and economically promising solution to the freedmen problem, all the while being embroiled in 
a tug-of-war with the Johnson Administration over the technicalities of Reconstruction policy.

Historians have, for most of the twentieth century, been on opposite sides of the line drawn between the Freedmen's Bureau's conflicting identities. Rarely in the century following the dissolution of the Bureau did historians contextualize the complex nature of Reconstruction and it's effect on the success of the Freedmen's Bureau. In 1988, Eric Foner released his book Reconstruction: America's Unfinished Revolution, 1863 - 1877. Foner crafted an image of the Bureau that continues to influence historians. According to Foner, the Bureau was grounded in a naïve belief in the potential of a free labor market that could transcend the racial tensions and animosity of the post war south: "Perhaps the greatest failing of the Freedmen's Bureau was that it never quite comprehended the depths of racial antagonisms and class conflict in the postwar south."xxxii Foner presented an image of the Bureau that was split between the reality of its actions and the intentions of its leaders. When the Bureau opened its doors, a Tennessee agent professed that "the idea of free labor [was] the noblest principle on Earth."xxxiv Using this lens, Foner contextualizes the early decisions made my the leaders of the Bureau as earnest attempts to honor Sherman's Field Orders and their shared belief that settled land would be the most effective option for freedmen to enter and succeed in the free market.

Foner argues that the Bureau had for the most part been committed to the success of freedmen. However, the initial ranks of Bureau leaders who took the most radical approach to the establishment of ex-slaves did not last very long in office. Within a year of its inception, the first casts of radical leaders in the Bureau dedicated to the maintenance of colonies on the confiscated lands were no longer in office, and with them went many settler's hope. ${ }^{x x x}$ The Johnson administration did not support the aims of the Bureau officials, and for those who remained, Foner pointed out how the large amount of government interference retarded the success of the Bureau. The continued interference by the government pushed freedmen away from settlements and into the wage labor market, where Foner points out the continued attempts to guarantee protections to the freedmen by the Bureau. General 0. O. Howard announced after assuming office that labor agreements "should be free, bona fide acts." ${ }^{x x x v i}$ Foner critiques the naivety of the upper ranks of Bureau officials, especially Howard, because this idealistic intention was unrealistic in the post war South: "How "voluntary" were labor contracts agreed to by blacks when they were denied access to land, coerced by troops and Bureau agents if they refused to sign, and fined or imprisoned if they struck for higher wages."xxxvii Foner acknowledges that there was no uniformity in commitment to the freedmen cause within the levels of the Bureau. As stated above, Bureau agents on the ground were equally detrimental to the success of freedmen as their racist Southern peers. Identifying the conflicting forces working within the Bureau was a unique approach in its histories as Foner built off of the conflicting identities established over the twentieth century and elaborated on arguments that relegated the Bureau to one side of the victim/oppressor binary. Foner contextualized the Bureau by its naive intentions, its adherence to the Johnson Administrations policies, and by the stories of Bureau agents for and against the success of freedmen. He combined them all to craft a lasting image of a Bureau at war with itself and with outside forces.

In 2001 Akiko Ochiai wrote a paper "The Port Royal Experiment Revisited: Northern Visions of Reconstruction and the Land Question," that established the complicated political climate that forced the hand of the Freedmen's Bureau when making its policy decisions. 
Ochiai states, "From the outset, then, the Port Royal Experiment found itself caught between African Americans' desires to own their homelands, on which they expected to operate a sustainable subsistence economy, and Northern capitalists' visions of freed people's cheap wage labor on white controlled commercial plantations, with the prospect of trickle-down prosperity and education for citizenship." xxxviii Ochiai explains that the Freedmen's Bureau was not simply on one side or the other, but forced to adhere to the pressures of both Freedmen and the Northern capitalist system that dominated the political atmosphere of the time. Ochiai contextualizes the Freedmen's Bureau in contemporary terms by comparing some of its policies to that of Affirmative Action policies, arguing that the Freedman's Bureau intended to offer opportunities for Freedmen to step into the competitive landscape of capitalist culture unaffected. .xxix $^{\text {. }}$

There are many histories written about the Freedmen's bureau other than the select few that are here, however, these examples are representative of the changing discourse on the Freedmen's Bureau and it's role in the Reconstruction. By tracking the arguments comparatively, there exists a visible change from the early 1920's with Thompson, who suggested that the society at large feared Freedmen's dependency on government money shaped the economic policies that went into place. The transition from this throughout the twentieth century to the vilification of the Freedmen's Bureau and its role in establishing an exploitive wage labour system that mirrored slave labor can be traced through the historical arguments being made in these articles. In constrast, the opposite argument, which traces the attempts of the Freedmen's bureau to secure any form of rights for Freedmen and the subsequent obstacles that prevented their success, can also be traced throughout the same time frame. The culmination being that of recent histories that blend these two historical identities to craft an image that is representative of the complexities of Reconstruction politics and of a Freedmen's Bureau trying to work within an established system to ensure the successful assimilation of Freedmen into the U.S. economy and the U.S. society at large.

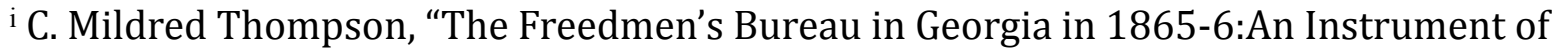
Reconstruction." The Georgia Historical Quarterly, Vol. 5, No. 1 (March, 1921): 40.

ii Ibid.

iii Ibid., 49

iv Ibid.

v Ibid., 49

viMartin Abbot, "Free Land, Free Labor, and the Freedmen's Bureau." Agricultural History, Vol. 30, No. 4 (Oct., 1956): 151

vii Ibid., 152

viiiClaude F. Oubre, "'Forty Acres and a Mule': Louisiana and the Southern Homestead Act. Louisiana History: The Journal of the Louisiana Historical Association, Vol. 17, No. 2 (Spring, 1976): 144

ix Ibid.,146

x Ibid., 149

xi Ibid., 157 
xii James Oakes, "A Failure of Vision: The Collapse of the Freedmen's Bureau Courts." Civil War History, Vol. 25. No. 1 (March, 1979): 745

xiii Ibid., 71

xiv Ibid., 75

xv Ibid., 73

xviHerman Belz, "The Freedmen's Bureau Act of 1865 and the Principle of No Discrimination According to Color." Civil War History, Vol. 21, No. 3 (September 1975): 207

xvii William Cohen, "Black Immobility and Free Labor: The Freedmen's Bureau and the Relocation of Black Labor, 1865-1868." Civil War History, Vol. 30, No. 3 (September, 1984): 221

xviii Litwack, Leon F. Been In The Storm So Long: The Aftermath of Slavery. (New York: Random House, Inc. 1979), 381.

xix Ibid.

xx Ibid. 386

xxi Belz, “The Freedmen's Bureau Act of 1865," Civil War History, 198.

xxii Litwack, Been in The Storm, 385

xxiii Belz, “The Freedmen's Bureau Act of 1865," Civil War History, 197

xxiv Cohen, "Black Immobility and Free Labor: The Freedmen's Bureau and the Relocation of Black Labor, 1865-1868." Civil War History, 222

xxv Ibid., 223

xxvi Paul A. Cimbala, “The Freedmen's Bureau, the Freedmen, and Sherman's Grant in Reconstruction Georgia, 1865-1867. The Journal of Southern History, Vol. 55, No. 4 (Nov., 1989), 598

xxvii Ibid., 602

xxviii Ibid., 605

xxix Ibid., 622

xxx Ibid., 603

xxxi Willie Lee Rose, Rehearsal for Reconstruction: The Port Royal Experiment eBook. (Oxford University Press. 1964) 355.

xxxii Ibid., 356

xxxiii Eric Foner. Reconstruction: America's Unfinished Revolution 1863-1877. (New York: Harper and Row, Publishers. 1988),170.

xxxiv Ibid., 155

xxxv Ibid., 161

xxxvi Ibid., 166

xxxvii Ibid. 
xxxviii Akiki Ochiai, "The Port Royal Experiment Revisited: Northern Visions of Reconstruction and the Land Question." The New England Quarterly, Vol. 74, No. 1 (Mar., 2001), 96 xxxix Ibid, 108. 
Bibliography

Abbott, Martin. "Free Land, Free Labor, and the Freedmen's Bureau." Agricultural History, Vol. 30, No. 4 (Oct., 1956), pp. 150-56. http://www.jstor.org/stable/3740455

Belz, Herman. “The Freedmen's Bureau Act of 1865 and the Principle of No Discrimination According to Color." Civil War History, Vol. 21, No. 3 (September 1975), pp. 197 -217. Kent State University Press.

Cimbala, Paul A. “The Freedmen's Bureau, the Freedmen, and Sherman's Grant in Reconstruction Georgia, 1865-1867. The Journal of Southern History, Vol. 55, No. 4 (Nov., 1989), pp. 597-632. Southern Historical Association. http://www.jstor.org/ stable/2209042

Cohen, William. "Black Immobility and Free Labor: The Freedmen's Bureau and the Relocation of Black Labor, 1865-1868." Civil War History, Vol. 30, No. 3 (September, 1984), pp. 221-234. Kent State University Press.

Farmer-Kaiser, Mary. "Are they not in some sorts vagrants?": Gender and the Efforts of the Freedmen's Bureau to combat Vagrancy in the Reconstruction South. The Georgia Historical Quarterly, Vol. 88, No. 1 (Spring, 2004), pp 25-49. http://www.jstor.org/ stable/40584704

Finkenbine, Roy E. “Wendell Phillips and “The Negro's Claim”: A Neglected Reparations Document." Massachusetts Historical Review, Vol. 7. (2005) 105-19. Web. Accessed February 07th, 2015. http://www.jstor.org/stable/25081197.

Foner, Eric. "The Civil War and the Story of American Freedom." Art Institute of Chicago Museum Studies, Vol. 27, No. 1, Terrain of Freedom: American Art and the Civil War (2001), pp. 8-25 +100-1. The Art Institute of Chicago. http://www.jstor.org/stable/ 4102836

Foner, Eric. Reconstruction: America's Unfinished Revolution 1863-1877. New York: Harper 